\title{
Glandular Odontogenic Cyst: Review of Literature and Report of a New Case with Cytokeratin-19 Expression
}

\author{
Marco Mascitti ${ }^{1, *}$, Andrea Santarelli ${ }^{1,2}$, Antonio Sabatucci ${ }^{1}$, Maurizio Procaccini ${ }^{1,2}$, Lorenzo Lo \\ Muzio $^{3}$, Antonio Zizzi ${ }^{4}$ and Corrado Rubini ${ }^{4}$ \\ ${ }^{I}$ Department of Clinic Specialistic and Odontostomatological Sciences, Polytechnic University of Marche, Ancona, Italy \\ ${ }^{2}$ Institute of Health and Science on Aging INRCA, Ancona, Italy \\ ${ }^{3}$ Department of Sperimental and Clinical Medicine, University of Foggia, Foggia, Italy \\ ${ }^{4}$ Department of Biomedical Sciences and Public Health, Polytechnic University of Marche, Ancona, Italy
}

\begin{abstract}
The glandular odontogenic cyst (GOC) was a rare jawbone cyst described in 1988 as a distinct entity. This lesion can involve either jaw, and the anterior region of the mandible was the most commonly affected area. Clinical and radiographic findings were not specific, and the diagnosis of GOC can be extremely difficult due to the rarity of this lesion. The cyst presented a wall constituted by fibrous connective tissue and was lined by a non-keratinized stratified squamous epithelium of variable thickness. Large areas of the lining epithelium presented cylinder cells, sometimes ciliated. A variable amount of mucina was occasionally noted. Due to the strong similarities, this cyst can be easily misdiagnosed as a central mucoepidermoid carcinoma (CMEC). Immunohistochemistry may be an aid in diagnosis; in fact has been demonstrated that there were differences in the expression of cytokeratins (CK) in GOC and CMEC. In this study, we reported a new case of GOC in a 38 year female patient. In addition, we carried out a review of 110 previous cases reported in literature.
\end{abstract}

Keywords: Cytokeratins, Glandular odontogenic cyst, Odontogenic cyst.

\section{INTRODUCTION}

The glandular odontogenic cyst (GOC) is an uncommon cyst of the jaws, locally aggressive and with recurring potential $[1,2]$, which poses a diagnostic and therapeutic challenge. In 1987, Padayachee and Van Wyk [3] described two cystic lesions with histologic features that did not fit into the known classification of cysts, who called "sialo-odontogenic cyst". One year later Gardner et al. [4] described eight cases with similar histological appearance and suggested the term "glandular odontogenic cyst". In 1992, the WHO [1] named the GOC an independent pathologic entity and classified it as a developmental odontogenic cyst.

Clinically, the most common site of occurrence is the mandible, especially in the anterior region, presenting as an asymptomatic swelling [5]. This lesion appear as an unilocular or multilocular radiolucency, usually with well-defined margins and in some cases scalloped borders [6]. However, there are no pathognomonic radiological features for GOC [7].

\footnotetext{
*Address correspondence to this author at the Department of Clinic Specialistic and Odontostomatological Sciences, Polytechnic University of Marche, Ancona, Italy; Tel: +39-071-2206226; Fax: +39-071-2206221;

E-mail: marcomascitti86@hotmail.it
}

The exact microscopic criteria necessary for diagnosis have not been universally accepted, leading to the consideration that this lesion may not be as rare as it has been considered. In fact, it has been suggested that many cases formerly diagnosed as central mucoepidermoide carcinoma (CMEC) can be cases of GOC and some low-grade CMECs would have originated from GOCs [8]. The reason was that a considerable overlap between histological features of GOC and CMEC was present [9], and some authors suggested the hypothesis that GOC and CMEC of the jaws represent a spectrum of one disease [10]. Thus, several attempts to use molecular markers to facilitate the diagnosis had been made. Some hopeful markers were cytokeratins (CK), mostly CKs 18 and 19, whose expression profile was found different in these two lesions [11].

Due to high recurrence rate and aggressive growth potential [12], some authors believe that marginal resection may be a more reliable treatment for GOC [13]. In the literature, both conservative and radical methods of treatment of GOC have been suggested, but due to the rarity of the condition, treatment recommendations were not evidence based [14, 15]. The prognosis of this cyst still remained unclear, and follow-up should last several years after treatment [16].

In this article, we presented a new case of GOC and conducted a review of literature, taking into consideration 110 


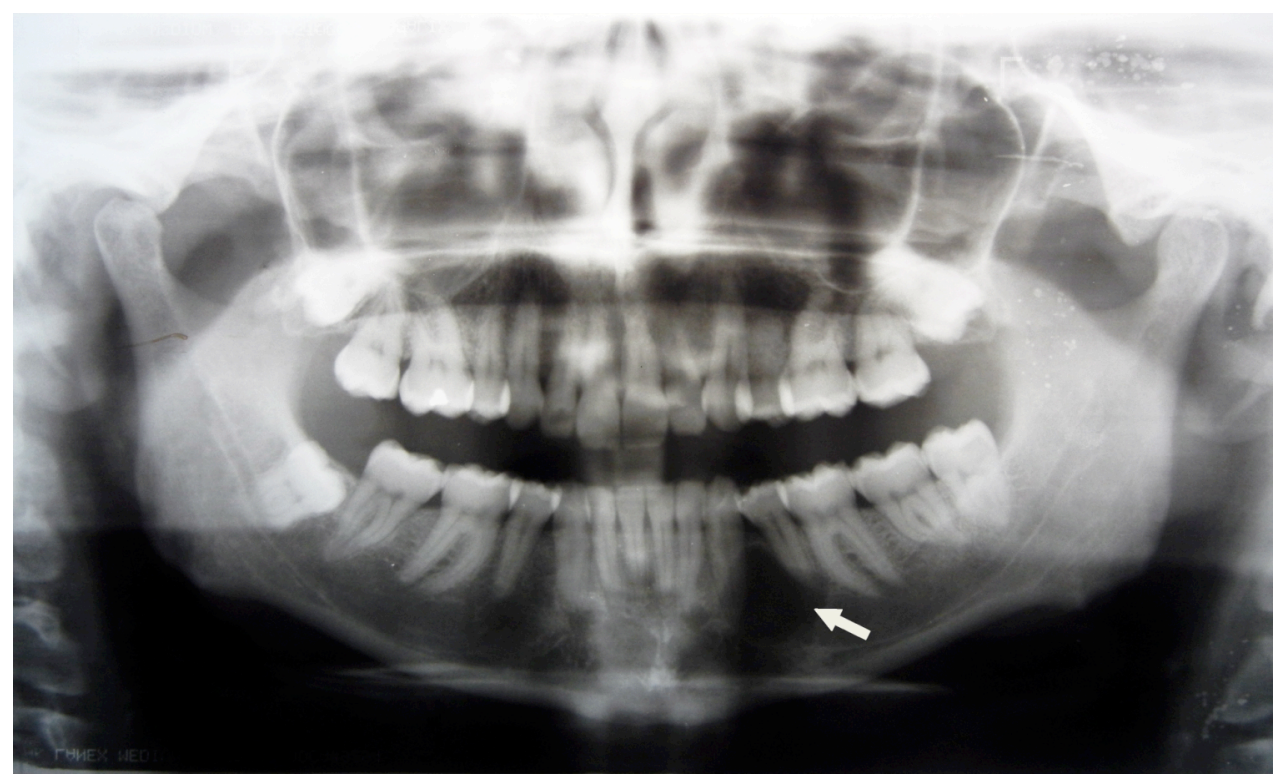

Fig. (1). Radiography shows a well-defined, unilocular lesion extending in the anterior body of the left mandible.

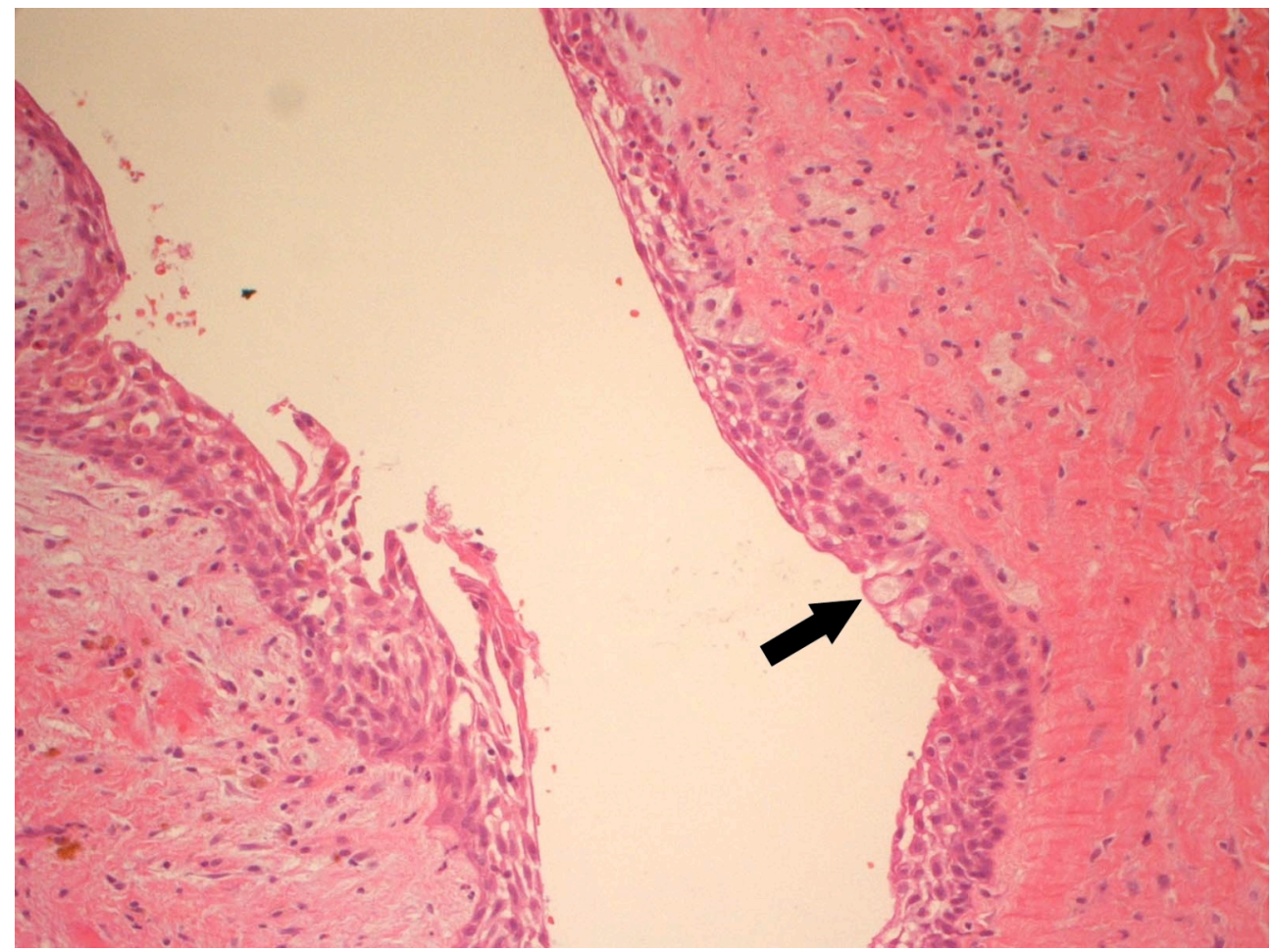

Fig. (2). Cystic lesion showing variable thickness of the epithelium lining with metaplastic mucous cells (x20).

previous cases, focusing on epidemiology, clinico-pathologic and radiologic features as well as biologic behavior.

\section{MATERIAL AND METHODOLOGY}

In October 2011, a 38-years-old woman was admitted at the University Hospital "Ospedali Riuniti" in Ancona, Italy, with a radiolucent lesion in the anterior mandible. The lesion was asymptomatic and was discovered as an incidental finding by a dentist some months before. The patient's medical history was not significant. Oral examination showed normal appearance and color of mucosa. Radiographic examination showed a well-defined, unilocular lesion extending in the left mandible anterior body (Fig. 1). The lesion was extended in an intraradicular position, with superior limits ranging between the roots of the canine and the first and second premolar. The teeth were all vital. The lesion was subjected to surgical enucleation, and the material was sent for histopathological examination. Histological analysis of the lesion revealed a cyst wall with focally ciliated epithelium lining of variable thickness. The superficial layer of the epithelium showed metaplastic mucous cell with intraepithelial microcystic area (Fig. 2, 3 and 4). The results of immunohistochemistry revealed strong positive activity for CK 19 in all 


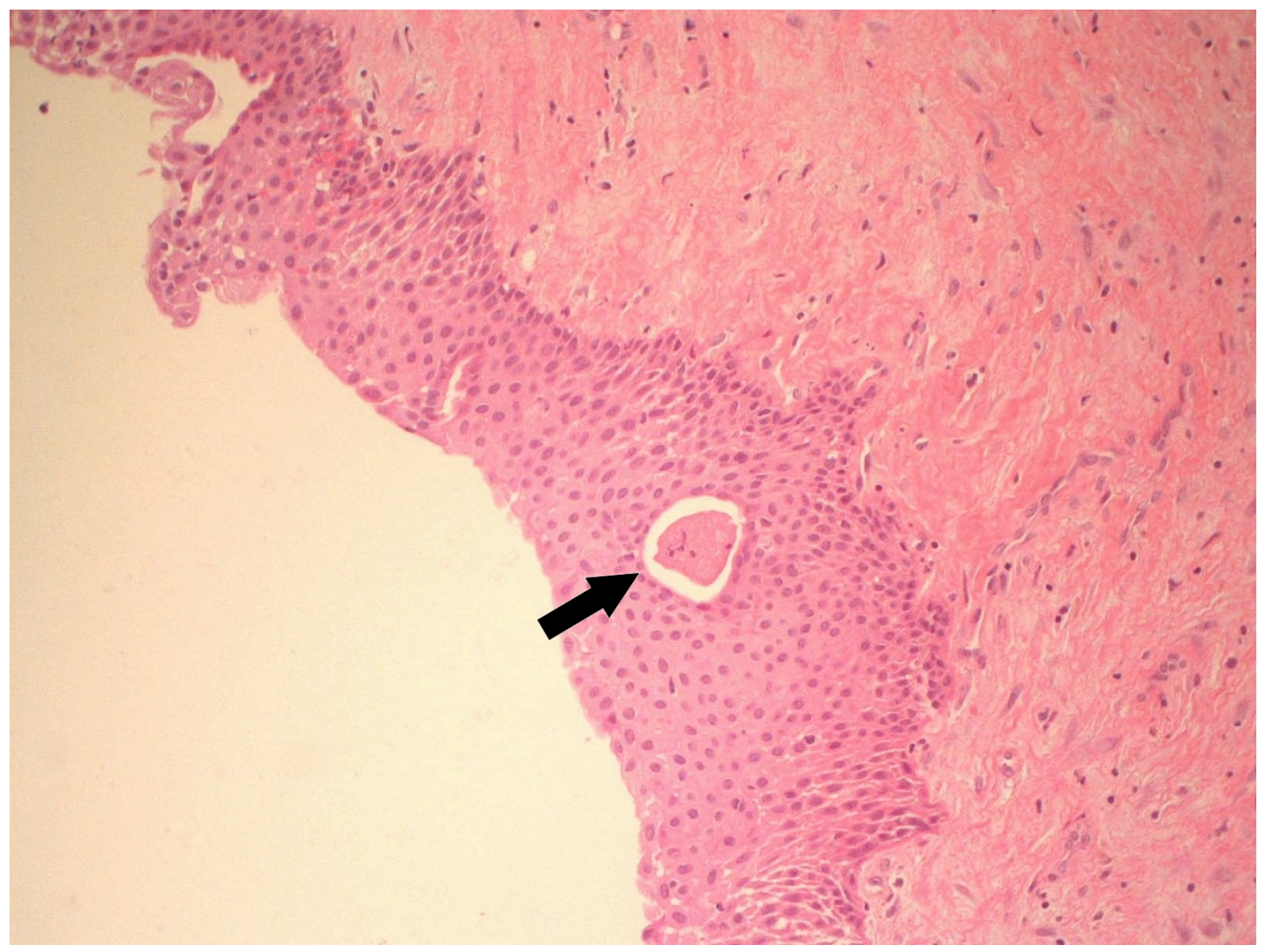

Fig. (3). Lining epithelium with microcystic area (x20).

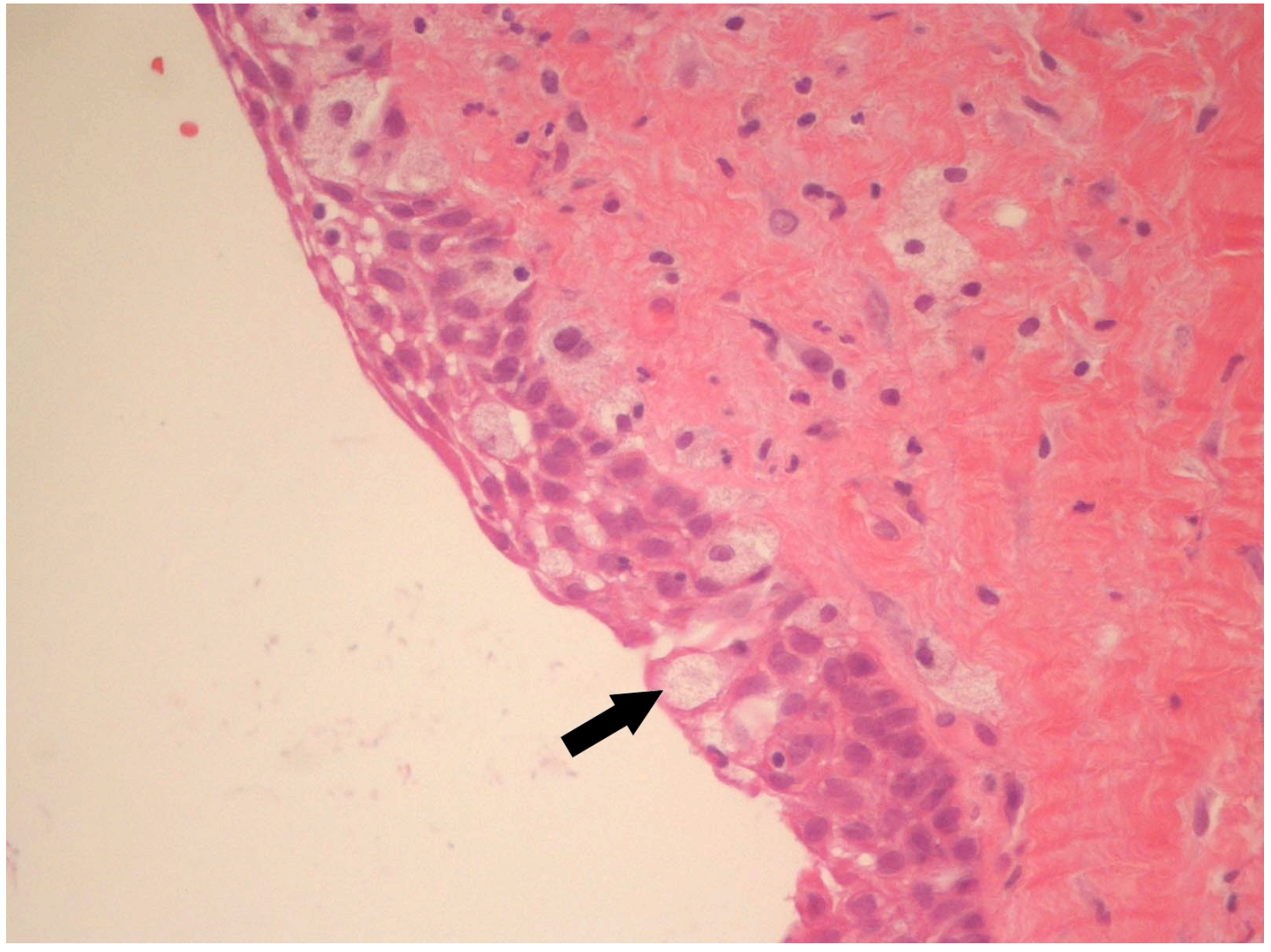

Fig. (4). High magnification of mucous cells (x40). 


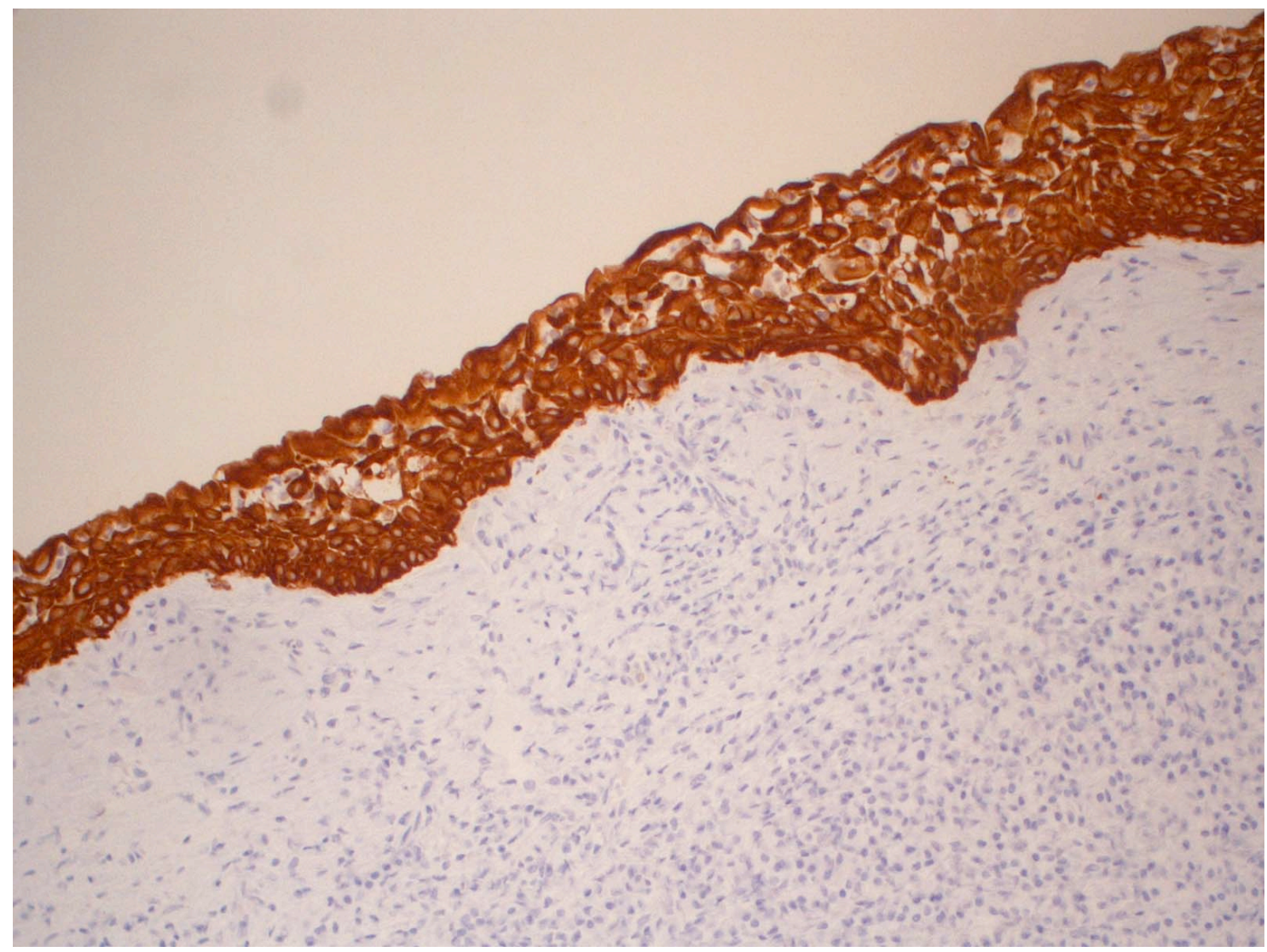

Fig. (5). Immunohistochemical expression of CK19 shows strong positivity in all layers of the epithelium (x20).

layer of the epithelium (Fig. 5). The final diagnosis was glandular odontogenic cyst. The postoperative course was uneventful. Intraoral examination and radiographic evaluations by OPT every 6 months showed no recurrence during the 12 months follow-up period.

\section{DISCUSSION}

The Glandular odontogenic cyst is a rare lesion, with a frequency rate ranging from $0.012 \%$ [17] to $1.3 \%$ [18] of all jaw cists, and its prevalence is $0.17 \%$ [19].

The literature review took into consideration 110 previous cases, with one more additional case presented in this article (Table 1). The main features of GOC are summarized in Table 2. The patient ages ranged from 11 to 90 years, and the majority of cases were reported in patient between 40 and 60 years of age (49 cases), with a mean age at diagnosis of 45.2 years ( 43.4 for males, 47.4 for females). The prevalence of this lesion was slightly more common in men, comprising 53.2\% (59 cases).

Glandular odontogenic cyst had a clear preference for the mandible, with $74.8 \%$ of cases in this region and only $25.2 \%$ in the maxilla. The $48.6 \%$ of glandular odontogenic cysts ( 54 cases, 37 in the mandible and 17 in the maxilla) was found in the anterior regions, $18.9 \%$ (21 cases, 18 in the mandible and 3 in the maxilla) in the posterior regions, and the remaining $32.5 \%$ (36 cases, 28 in the mandible and 8 in the maxilla) of cases involved both the anterior and posterior areas, suggesting a predilection for the anterior areas of the jaws (Table 3).
Swelling was the most common presenting manifestation of the GOC, reported in $76.3 \%$ of cases ( 74 cases, of which 60 were painless and 14 were associated with pain, probably due to pressure on neurovascular bundles [20]). In $9.3 \%$ of cases ( 9 cases), the only clinical manifestation was pain or discomfort. In $14.4 \%$ of cases, the GOC was asymptomatic (14 cases), and was discovered as an incidental finding. Other clinical manifestations were rare (inflammation / irritation of the overlying mucosa, tooth mobility / displacement, paresthesia) and can be associated with pain and / or swelling. No information was available on sign and symptoms for 13 cases.

Radiographically, the lesions typically presented as a radiolucent unilocular or multilocular lesion. These data highlights the absence of pathognomonic clinical or radiographic presentation of GOC, considering that the same features can be found in odontogenic keratocyst, unicystic or multicystic ameloblastoma, CMEC, lateral epithelial cyst and botryoid odontogenic cyst (BOC) [10]. The consequence was that the recognition of this cyst on base of physical and radiological examination was virtually impossible [8].

The histologenesis of GOC remain uncertain; in fact, it was initially suggested to develop from intraosseous salivary gland tissue [3]. Now most authors believe that these cysts originated from odontogenic epithelium $[7,21]$.

Histopathologically, some authors suggested that GOC may have a wide histologic spectrum ranging from cystic lesions resembling $\mathrm{BOC}$ to lesions resembling low-grade 
Table 1. Summary of clinical and radiological features, therapy, follow-up and eventual recurrence in 110 cases of glandular odontogenic cyst reported in the literature and the present case.

\begin{tabular}{|c|c|c|c|c|c|c|c|c|}
\hline $\begin{array}{l}\text { Author } \\
\text { (Year) }\end{array}$ & Age/ Sex & Presentation & $\begin{array}{c}\text { Region Affected } \\
\text { (Teeth) }\end{array}$ & $\begin{array}{l}\text { Radiological } \\
\text { Features }\end{array}$ & Treatment & Follow-up & Recurr. & $\begin{array}{l}\text { Interval } \\
\text { Before } \\
\text { Recurr. }\end{array}$ \\
\hline \multirow{2}{*}{$\begin{array}{c}\text { Padayachee } \text { et } \\
\text { al. (1987) }\end{array}$} & $69 / \mathrm{M}$ & Swelling & Ant. Mand. & Multiloc. RL & $\begin{array}{c}\text { Enucleation \& } \\
\text { curettage }\end{array}$ & 4 y \& $6 \mathrm{~m}$ & Yes & $3 y$ \\
\hline & $71 / \mathrm{F}$ & Swelling & Ant. Mand. & Multiloc. RL & $\begin{array}{c}\text { Enucleation \& } \\
\text { curettage }\end{array}$ & No & - & - \\
\hline \multirow{8}{*}{$\begin{array}{l}\text { Gardner et al. } \\
\text { (1988) }\end{array}$} & $21 / \mathrm{F}$ & - & Max.(22-23) & Uniloc. RL & Enucleation & 3 y \& $6 \mathrm{~m}$ & No & - \\
\hline & $59 / \mathrm{M}$ & Swelling & Mand.(33-43) & RL & Enucleation & 3 y $\& 8 \mathrm{~m}$ & Yes & 3 y $\& 8 \mathrm{~m}$ \\
\hline & $44 / F$ & - & Mand.(34-43) & RL & Enucleation & 3 y $\& 3 \mathrm{~m}$ & Yes & 3 y \& $3 \mathrm{~m}$ \\
\hline & $85 / F$ & - & Mand.(38-48) & Multiloc. RL & No & - & - & - \\
\hline & $59 / \mathrm{M}$ & - & Mand.(35-43) & RL & Curettage & $6 \mathrm{~m}$ & No & - \\
\hline & $44 / F$ & - & Max. (12-13) & RL & Enucleation & $2 \mathrm{y}$ & No & - \\
\hline & 19/M & Swelling & Mand.(36-43) & RL & Enucleation & $1 \mathrm{y}$ & No & - \\
\hline & 48/M & - & Ant. Mand. & RL & Enucleation & No & - & - \\
\hline $\begin{array}{l}\text { Lindh et al. } \\
\qquad(1990)\end{array}$ & $59 / \mathrm{M}$ & Swelling & Ant. Mand. & Multiloc. RL & Surgery & - & - & - \\
\hline $\begin{array}{c}\text { Ficarra et al. } \\
\text { (1990) }\end{array}$ & $64 / F$ & Swelling, pain & Ant. Mand. & Multiloc. RL & $\begin{array}{l}\text { Mandibular } \\
\text { resection }\end{array}$ & $2 y \& 10 \mathrm{~m}$ & No & - \\
\hline $\begin{array}{l}\text { Sadeghi et al. } \\
\qquad(1991)\end{array}$ & $73 / F$ & Swelling & Post. Mand. & Multiloc. RL & Enucleation & No & - & - \\
\hline \multirow{3}{*}{$\begin{array}{c}\text { Patron et al. } \\
\text { (1991) }\end{array}$} & $45 / \mathrm{M}$ & Swelling & Mand.(31-45) & Uniloc. RL & $\begin{array}{c}\text { Marginal } \\
\text { mandibulec- } \\
\text { tomy }\end{array}$ & $20 \mathrm{y}$ & No & - \\
\hline & $39 / \mathrm{M}$ & Swelling & Mand.(35-46) & $\begin{array}{l}\text { Multiloc. RL } \\
\text { root resorpt. }\end{array}$ & Enucleation & $10 \mathrm{y}$ & No & - \\
\hline & $52 / \mathrm{M}$ & Swelling & Max.(22-26) & $\begin{array}{l}\text { Uniloc. RL, root } \\
\text { resorpt. }\end{array}$ & $\begin{array}{l}\text { Partial Maxil- } \\
\text { lectomy }\end{array}$ & $14 \mathrm{y}$ & No & - \\
\hline \multirow{2}{*}{$\begin{array}{l}\text { Van Heerden } \\
\text { et al. }(1992)\end{array}$} & $14 / \mathrm{M}$ & Swelling & Max.(12-13) & $\begin{array}{l}\text { Uniloc. RL, tooth } \\
\text { displ. }\end{array}$ & No & - & - & - \\
\hline & $27 / F$ & Swelling & Mand.(36-45) & $\begin{array}{l}\text { Uniloc. RL, tooth } \\
\text { displ. }\end{array}$ & Enucleation & $2 y$ & No & - \\
\hline \multirow{4}{*}{$\begin{array}{c}\text { Günzl et al. } \\
\text { (1993) }\end{array}$} & $31 / \mathrm{M}$ & - & Ant. Mand. & Multiloc. RL & Excision & - & No & - \\
\hline & 39/M & - & Ant. Mand. & Multiloc. RL & Excision & - & No & - \\
\hline & $44 / F$ & - & Post. Mand. & Multiloc. RL & Excision & - & No & - \\
\hline & $52 / \mathrm{F}$ & - & Post. Mand. & Multiloc. RL & Excision & - & No & - \\
\hline $\begin{array}{l}\text { Semba et al. } \\
\text { (1994) }\end{array}$ & $72 / \mathrm{M}$ & Swelling, pain & Mand.(32-35) & $\begin{array}{l}\text { Multiloc. RL root } \\
\text { resorpt. }\end{array}$ & Excision & $2 \mathrm{y}$ & No & - \\
\hline $\begin{array}{l}\text { Takeda et al. } \\
\text { (1994) }\end{array}$ & $29 / \mathrm{M}$ & Discomfort & Mand.(48) & Uniloc. RL & Extirpation & $1 \mathrm{y} \& 2 \mathrm{~m}$ & No & - \\
\hline
\end{tabular}


Table 1. contd....

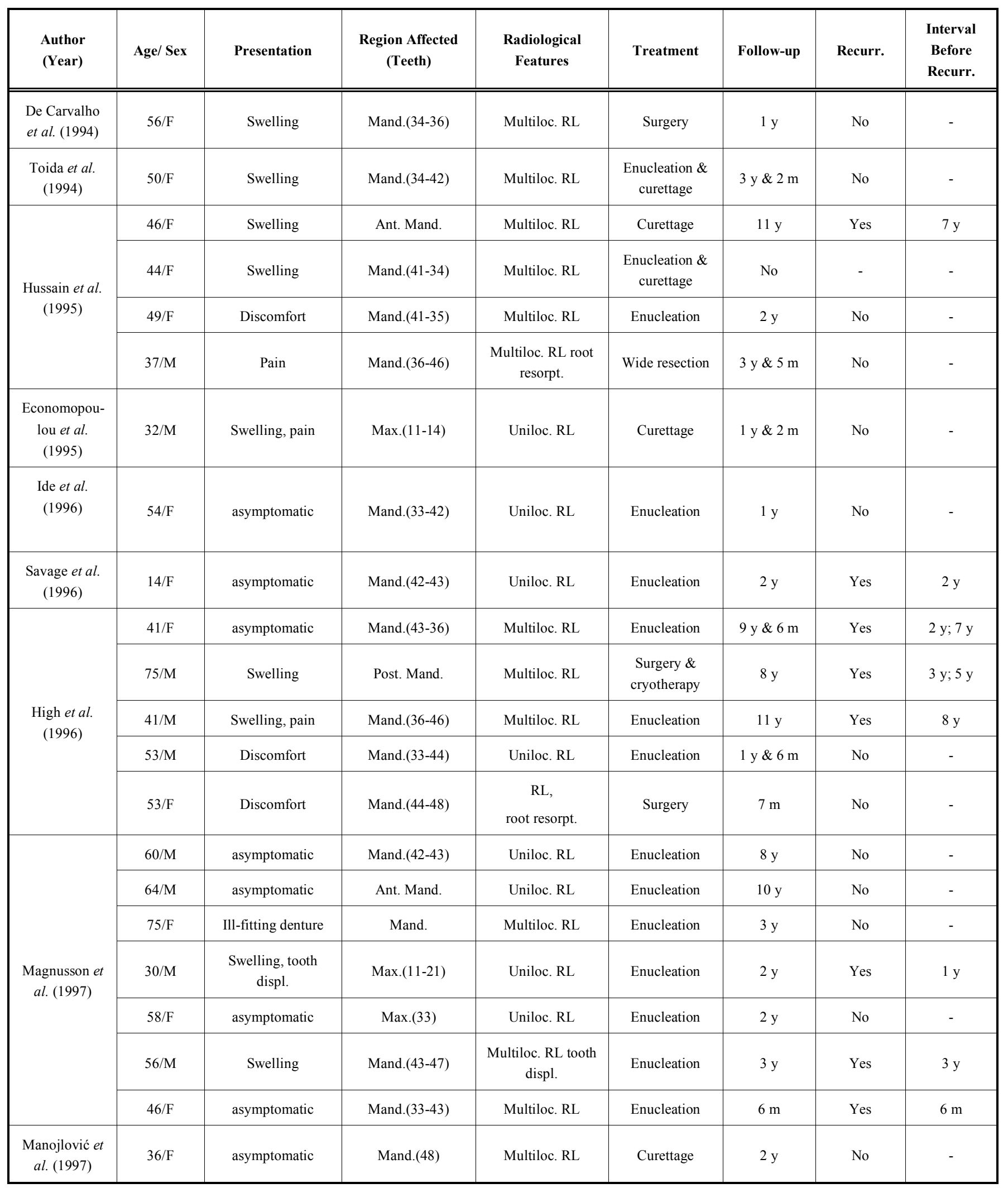


Table 1. contd...

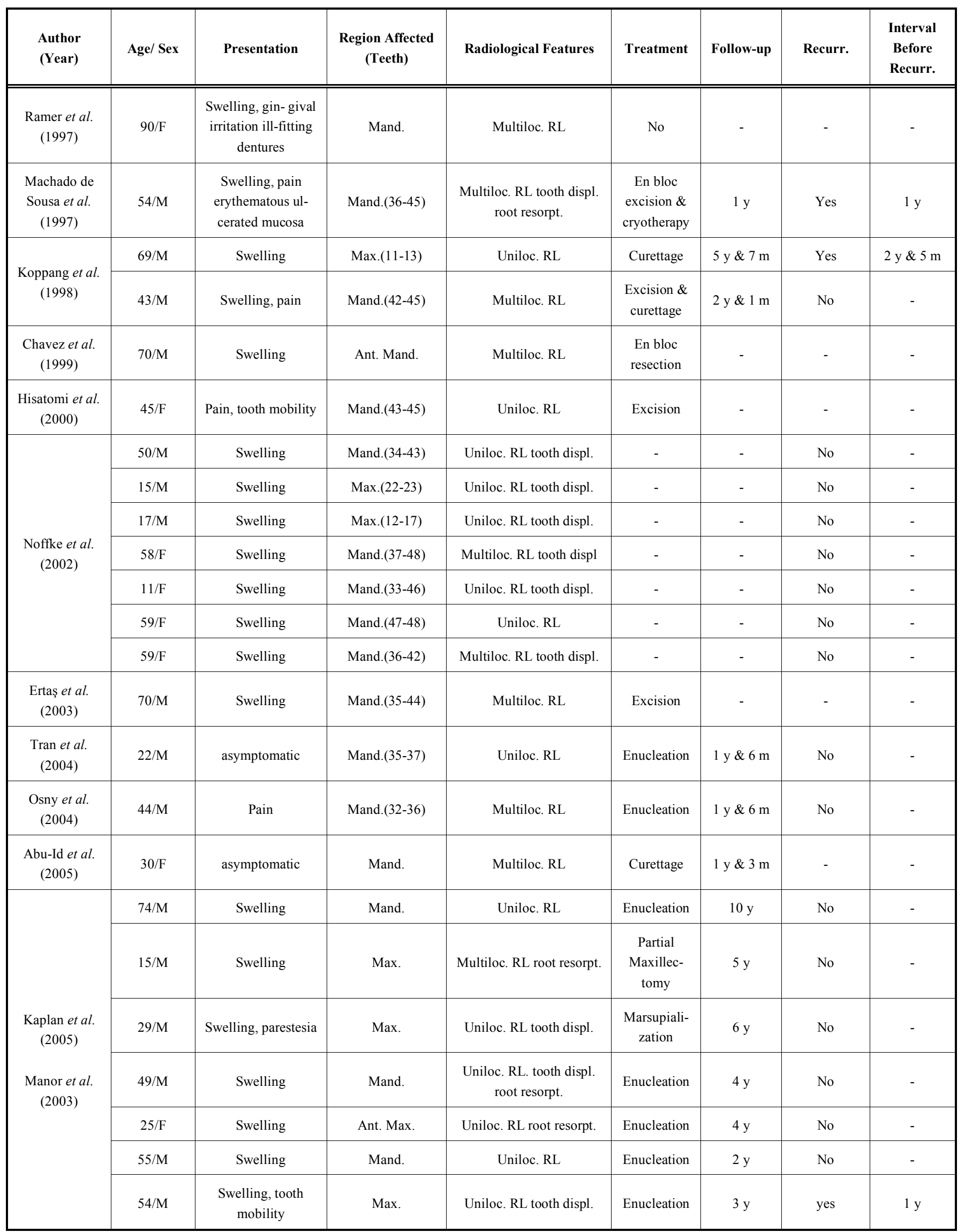


Table 1. contd...

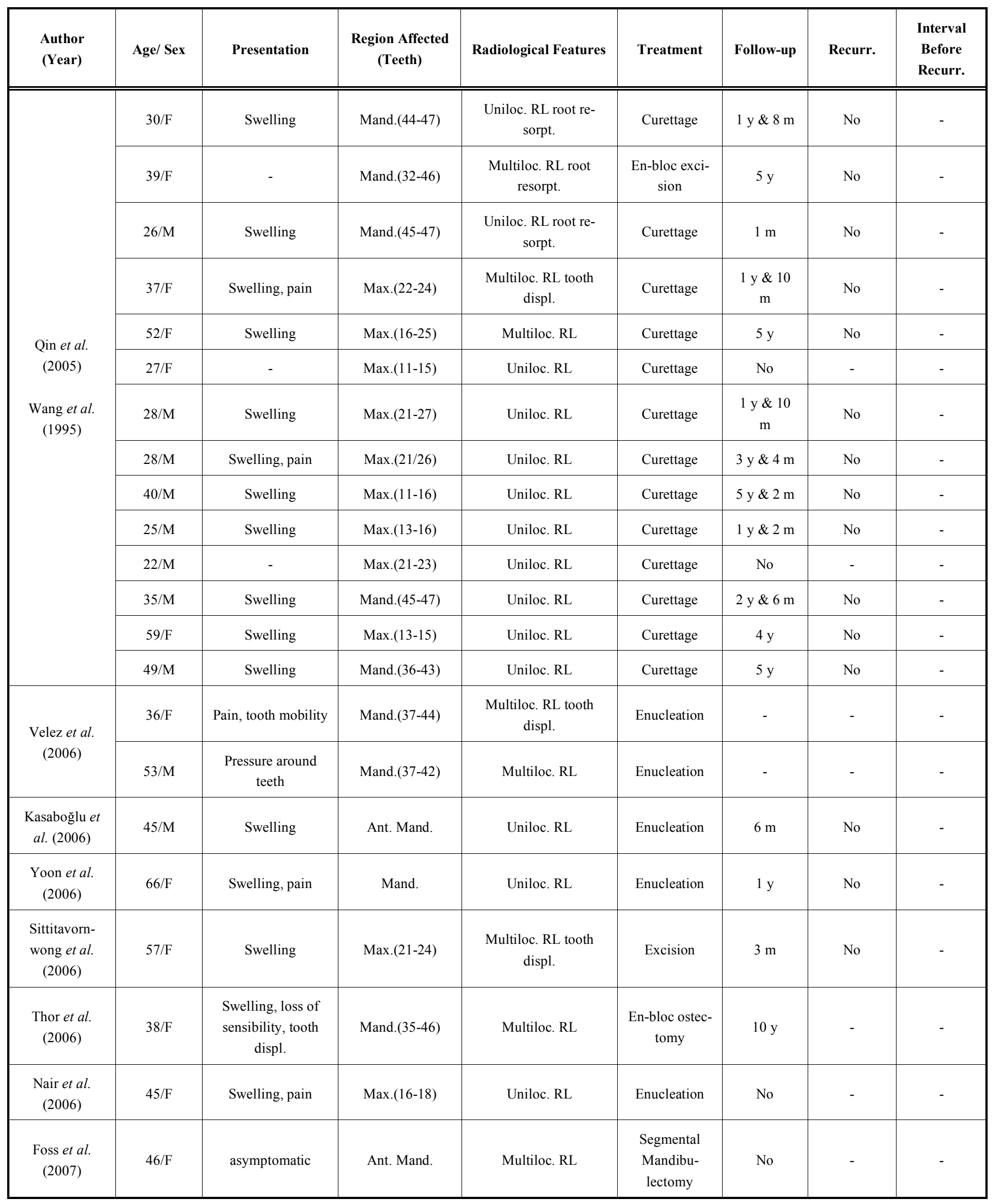


Table 1. contd....

\begin{tabular}{|c|c|c|c|c|c|c|c|c|}
\hline $\begin{array}{l}\text { Author } \\
\text { (Year) }\end{array}$ & Age/ Sex & Presentation & $\begin{array}{l}\text { Region Affected } \\
\text { (Teeth) }\end{array}$ & Radiological Features & Treatment & Follow-up & Recurr. & $\begin{array}{r}\text { Interval } \\
\text { Before } \\
\text { Recurr. }\end{array}$ \\
\hline $\begin{array}{c}\text { de Castro et al. } \\
\text { (2008) }\end{array}$ & $40 / \mathrm{F}$ & Swelling & Mand.(32-41) & Uniloc. RL & Enucleation & $1 \mathrm{y}$ & No & - \\
\hline $\begin{array}{c}\text { Kumaraswamy } \\
\text { et al. (2008) }\end{array}$ & $14 / \mathrm{M}$ & Swelling, pain & Mand.(43-48) & $\begin{array}{l}\text { Uniloc. RL root re- } \\
\text { sorpt. tooth displ. }\end{array}$ & Enucleation & $1 \mathrm{y}$ & No & - \\
\hline $\begin{array}{l}\text { Manzini et al. } \\
\quad \text { (2009) }\end{array}$ & $27 / \mathrm{F}$ & $\begin{array}{l}\text { Pain, pruritus, } \\
\text { inflammated mu- } \\
\text { cosa }\end{array}$ & Ant. Max. & Uniloc. RL & Enucleation & No & - & - \\
\hline $\begin{array}{l}\text { Oliveira et al. } \\
\text { (2009) }\end{array}$ & $54 / \mathrm{F}$ & Swelling & Mand.(31-35) & Multiloc. RL & Enucleation & $9 \mathrm{~m}$ & Yes & $9 \mathrm{~m}$ \\
\hline \multirow{2}{*}{$\begin{array}{c}\text { Krishnamurthy } \\
\text { et al. (2009) }\end{array}$} & $42 / \mathrm{F}$ & Swelling & Mand.(36-45) & Multiloc. RL & $\begin{array}{c}\text { En-bloc resec- } \\
\text { tion }\end{array}$ & $2 \mathrm{y}$ & No & - \\
\hline & $21 / \mathrm{M}$ & Swelling & Mand.(32-38) & Multiloc. RL & $\begin{array}{l}\text { En-bloc resec- } \\
\text { tion }\end{array}$ & $2 \mathrm{y}$ & No & - \\
\hline $\begin{array}{l}\text { Prabhu et al. } \\
\quad \text { (2010) }\end{array}$ & $47 / \mathrm{F}$ & Swelling & Max. & Uniloc. RL & Enucleation & $5 y$ & No & - \\
\hline $\begin{array}{l}\text { Lyrio et al. } \\
\text { (2010) }\end{array}$ & $37 / \mathrm{M}$ & Swelling & Mand.(41-48) & Multiloc. RL & Curettage & No & - & - \\
\hline $\begin{array}{l}\text { Booth et al. } \\
\quad(2010)\end{array}$ & $36 / \mathrm{M}$ & asymptomatic & Mand.(48) & Uniloc. RL & $\begin{array}{l}\text { Surgical } \\
\text { removal }\end{array}$ & $6 \mathrm{~m}$ & Yes & $6 \mathrm{~m}$ \\
\hline \multirow{2}{*}{$\begin{array}{l}\text { Boffano et al. } \\
\text { (2010) }\end{array}$} & $68 / \mathrm{M}$ & Swelling & Mand.(33-47) & Multiloc. RL & Curettage & $2 \mathrm{y}$ & No & - \\
\hline & $82 / \mathrm{F}$ & $\begin{array}{c}\text { Swelling, paresthe- } \\
\text { sia }\end{array}$ & Post. Mand. & Uniloc. RL & $\begin{array}{l}\text { En-bloc exci- } \\
\text { sion }\end{array}$ & $6 y$ & No & - \\
\hline \multirow{2}{*}{$\begin{array}{l}\text { Cano et al. } \\
\text { (2011) }\end{array}$} & $54 / \mathrm{M}$ & Swelling & Mand.(45-48) & Multiloc. RL & curettage & $3 y$ & No & - \\
\hline & $63 / \mathrm{F}$ & Swelling & Mand.(36-47) & Multiloc. RL & $\begin{array}{l}\text { Marsupiali- } \\
\text { zation }\end{array}$ & $3 y$ & No & - \\
\hline $\begin{array}{l}\text { Korkmaz et al. } \\
\quad \text { (2011) }\end{array}$ & $52 / \mathrm{M}$ & asymptomatic & Mand. & Multiloc. RL & Curettage & $6 y$ & No & - \\
\hline $\begin{array}{l}\text { Salehinejad et } \\
\text { al. (2011) }\end{array}$ & $28 / \mathrm{M}$ & Swelling & Mand.(45-47) & $\begin{array}{l}\text { Uniloc. RL root re- } \\
\text { sorpt. }\end{array}$ & Enucleation & $2 \mathrm{y}$ & No & - \\
\hline $\begin{array}{l}\text { Amberkar et } \\
\text { al. (2011) }\end{array}$ & $29 / \mathrm{M}$ & Swelling, pain & $\begin{array}{c}\text { Max.(13-17, 23- } \\
\text { 27) }\end{array}$ & Uniloc. RL & - & - & - & - \\
\hline $\begin{array}{c}\text { Guruprasad et } \\
\text { al. (2011) }\end{array}$ & $17 / \mathrm{F}$ & Swelling, pain & Post. Max. & Uniloc. RL & $\begin{array}{c}\text { Enucleation \& } \\
\text { curettage }\end{array}$ & $1 \mathrm{y}$ & No & - \\
\hline $\begin{array}{c}\text { Araújo de } \\
\text { Morais (2012) }\end{array}$ & $56 / \mathrm{M}$ & Swelling, pain & Mand.(41-45) & Uniloc. RL & $\begin{array}{c}\text { Enucleation \& } \\
\text { curettage }\end{array}$ & $8 \mathrm{~m}$ & No & - \\
\hline Present case & $38 / \mathrm{F}$ & asymptomatic & Mand.(33-35) & Uniloc. RL & Enucleation & $12 \mathrm{~m}$ & No & - \\
\hline
\end{tabular}

$\mathrm{RL}=$ radiolucency; Multiloc. $=$ multilocular; Uniloc. $=$ unilocular; Ant. Mand. $=$ anterior mandible; Post. Mand. $=$ posterior mandible; Ant. Max. $=$ anterior maxilla; Post. Max $=$ posterior maxilla; resorpt..=resorption; displ.=displacement; $\mathrm{y}=$ year; $\mathrm{m}=$ month; 
Table 2. GOC main features.

\begin{tabular}{|c|c|}
\hline Mean Age & 45.2 Years \\
\hline Gender & $\begin{array}{c}53 \% \text { males } \\
47 \% \text { females }\end{array}$ \\
\hline Place & $\begin{array}{l}74.8 \% \text { Mandible } \\
25.2 \% \text { Maxilla }\end{array}$ \\
\hline Clinical presentation & $\begin{array}{c}75.3 \% \text { painful/painless swelling } \\
14.4 \% \text { asymptomatic } \\
9.3 \% \text { pain/discomfort }\end{array}$ \\
\hline Radiographic features & $\begin{array}{l}51.0 \% \text { unilocular } \\
49.0 \% \text { multilocular }\end{array}$ \\
\hline Treatment & $\begin{array}{c}86.5 \% \text { conservative } \\
13.5 \% \text { aggressive }\end{array}$ \\
\hline Mean follow-up period & 3 years and 7 months \\
\hline Recurrence & $19.8 \%$ of cases ( 3 years) \\
\hline
\end{tabular}

Table 3. GOC location.

\begin{tabular}{|c|c|c|c|}
\hline & Mand. & Max. & Mand. \& Max. \\
\hline \hline Ant. & $33.3 \%$ & $15.3 \%$ & $48.6 \%$ \\
\hline Post. & $16.2 \%$ & $2.7 \%$ & $18.9 \%$ \\
\hline Ant.\&Post. & $25.2 \%$ & $7.3 \%$ & $32.5 \%$ \\
\hline Total & $74.8 \%$ & $25.2 \%$ & $100.0 \%$ \\
\hline
\end{tabular}

Ant. $=$ anterior; Post. $=$ posterior; Mand. $=$ mandible; Max. $=$ maxilla

CMEC [22]. In particular, the differentiation of low-grade CMEC from multicystic GOC can be difficult to make, because significant histological overlap existed [5]. For these reasons, it has been suggested that many cases formerly diagnosed as CMEC can be examples of GOC as well as some low grade CMEC's would have originate from GOC $[8,11]$.

Kaplan et al. [2] divided the microscopic characteristic of GOC into major and minor criteria, with the purpose of facilitate the diagnosis. According to this author, a certain diagnosis of GOC could be made with the presence of all the major signs. The major criteria include:

1. Squamous epithelial lining, with a flat interface with the connective tissue wall, lacking basal palisading.

2. Epithelium exhibiting variations in thickness along the cystic lining with or without epithelial "spheres" or "whorls" or focal luminal proliferation.

3. Cuboidal eosinophilic cells or "hob-nail" cells.

4. Mucous cells with intraepithelial mucous pools, with or without crypts lined by mucous-producing cells.
5. Intraepithelial glandular, microcystic or duct-like structures.

The minor criteria include:

1. Papillary proliferation of the lining epithelium.

2. Ciliated cells.

3. Multicystic or multiluminal architecture.

4. Clear or vacuolated cells in the basal or spinous layers.

However, the practical applicability of the abovesuggested criteria may encounter some difficulties [23]. Moreover, some authors do not believe that all "major criteria" need to be present for diagnosis, but it is likely a combination of specific microscopic features to be important [23].

The present case showed some of the Kaplan's histopathological criteria, such as the epithelium lining of variable thickness, mucous cells and intraepithelial microcystic area.

Due to the strong similarities between GOC and CMEC, immunohistochemistry may help diagnosis. Pires et al. [11] 
have demonstrated that there are differences in the expression of $\mathrm{CKs}$ in GOC and CMEC, and suggested that CKs 18 and 19 could be useful in differentiating between these two lesions. Consistent with previous studies [11, 19, 22, 24], our results showed strong positivity in all layers of the epithelium for CK 19.

Many others molecular markers were investigated as new tools to diagnose GOC [25-28]. It has been suggested the use of Ki67 to distinguish GOC from CMEC [25]. Vered et al. [26] found levels of MASPIN (mammary serine protease inhibitor) significantly higher in the epithelial-mucous cells of CMEC than in GOC, that may help the differential diagnosis. Another marker was p63; immunostaining showed that this protein was confined to the basal and parabasal layers of the epithelium, with stained cells composed between $5 \%$ and $50 \%$ of the total [27].

Several methods of treatment of GOC, ranging from a conservative approach to a segmental resection, have been suggested [10], but the details of these surgical operations were not uniformly available. Furthermore, due to the rarity of the condition, treatment recommendations were not evidence based [15]. In 96 cases in which the surgical operations were reported, $86.5 \%$ of cysts ( 83 cases) were treated with a conservative method (like present case) while $13.5 \%$ (13 cases) received a more aggressive approach.

The reported recurrence of GOC was 19.8\% (18 cases), but probably was an under-estimation, because 31 cases lacks follow-up informations. Furthermore, about $50 \%$ of cases had a very short follow-up, up to 2 years, while the average time for recurrence was 3 years. Therefore is important that patients with GOC maintain a long follow-up period, that should exceed 3 years, to precociously diagnose eventual recurrences, that can recur even after many years [29].

\section{CONCLUSION}

In terms of establishing a diagnosis of GOC, must be taken into consideration the fact that this is a rare lesion, and diagnosis can be extremely difficult due to the strong similarities with CMEC. It is also important that patients maintain a long follow-up period that could last up to 8 years.

\section{CONFLICT OF INTEREST}

The authors confirm that this article content has no conflicts of interest.

\section{ACKNOWLEDGEMENTS}

Declared none.

\section{REFERENCES}

[1] Kramer IRH, Pindborg JJ, Shear M: Histological typing of odontogenic tumors. $2^{\text {nd }}$ ed. Berlin, Springer-Verlag 1992.

[2] Kaplan I, Anavi Y, Hirshberg A. Glandular odontogenic cyst: a challenge in diagnosis and treatment. Oral Dis 2008; 14(7): 575.

[3] Padayachee A, Van Wyk CW. Two cystic lesions with features of both the botryoid odontogenic cyst and the central mucoepidermoid tumour: sialo-odontogenic cyst? J Oral Pathol 1987; 16(10): 499.
[4] Gardner DG, Kessler HP, Morency R, Schaffner DL. The glandular odontogenic cyst: an apparent entity. J Oral Pathol 1988; 17(8): 359.

[5] Krishnamurthy A, Sherlin HJ, Ramalingam K, et al. Glandular odontogenic cyst: report of two cases and review of literature. Head Neck Pathol 2009; 3(2): 153.

[6] Noffke C, Raubenheimer EJ. The glandular odontogenic cyst: clinical and radiological features; review of the literature and report of nine cases. Dentomaxillofac Radiol 2002; 31(6): 333.

[7] Araujo de Morais HH, Jose de Holanda Vasconcellos R, de Santana Santos T, Guedes Queiroz LM, Dantas da Silveira EJ. Glandular odontogenic cyst: case report and review of diagnostic criteria. J Craniomaxillofac Surg 2012; 40(2): e46.

[8] Salehinejad J, Saghafi S, Zare-Mahmoodabadi R, Ghazi N, Kermani H. Glandular odontogenic cyst of the posterior maxilla. Arch Iran Med 2011; 14(6): 416.

[9] Waldron CA, Koh ML. Central mucoepidermoid carcinoma of the jaws: report of four cases with analysis of the literature and discussion of the relationship to mucoepidermoid, sialodontogenic, and glandular odontogenic cysts. J Oral Maxillofac Surg 1990; 48(8): 871

[10] Boffano P, Cassarino E, Zavattero E, Campisi P, Garzino-Demo P. Surgical treatment of glandular odontogenic cysts. J Craniofac Surg 2010; 21(3): 776.

[11] Pires FR, Chen SY, da Cruz Perez DE, de Almeida OP, Kowalski LP. Cytokeratin expression in central mucoepidermoid carcinoma and glandular odontogenic cyst. Oral Oncol 2004; 40(5): 545.

[12] Macdonald-Jankowski DS. Glandular odontogenic cyst: systematic review. Dentomaxillofac Radiol 2010; 39(3): 127

[13] Oliveira JX, Santos KC, Nunes FD, et al. Odontogenic glandular cyst: a case report. J Oral Sci 2009; 51(3): 467.

[14] Kaplan I, Gal G, Anavi Y, Manor R, Calderon S. Glandular odontogenic cyst: treatment and recurrence. J Oral Maxillofac Surg 2005; 63(4): 435.

[15] Cano J, Benito DM, Montans J, Rodriguez-Vazquez JF, Campo J, Colmenero C. Glandular odontogenic cyst: Two high-risk cases treated with conservative approaches. J Craniomaxillofac Surg 2012; 40(5): e131-6.

[16] Qin XN, Li JR, Chen XM, Long X. The glandular odontogenic cyst: clinicopathologic features and treatment of 14 cases. J Oral Maxillofac Surg 2005; 63(5): 694

[17] Magnusson B, Goransson L, Odesjo B, Grondahl K, Hirsch JM. Glandular odontogenic cyst. Report of seven cases. Dentomaxillofac Radiol 1997; 26(1): 26.

[18] van Heerden WF, Raubenheimer EJ, Turner ML. Glandular odontogenic cyst. Head Neck 1992; 14(4): 316.

[19] Shen J, Fan M, Chen X, Wang S, Wang L, Li Y. Glandular odontogenic cyst in China: report of 12 cases and immunohistochemical study. J Oral Pathol Med 2006; 35(3): 175.

[20] Koppang HS, Johannessen S, Haugen LK, Haanaes HR, Solheim T, Donath K. Glandular odontogenic cyst (sialo-odontogenic cyst): report of two cases and literature review of 45 previously reported cases. J Oral Pathol Med 1998; 27(9): 455.

[21] Gratzinger D, Salama ME, Poh CF, Rouse RV. Ameloblastoma, calcifying epithelial odontogenic tumor, and glandular odontogenic cyst show a distinctive immunophenotype with some myoepithelial antigen expression. J Oral Pathol Med 2008; 37(3): 177.

[22] de Sousa SO, Cabezas NT, de Oliveira PT, de Araujo VC. Glandular odontogenic cyst: report of a case with cytokeratin expression. Oral Surg Oral Med Oral Pathol Oral Radiol Endod 1997; 83(4): 478.

[23] Fowler CB, Brannon RB, Kessler HP, Castle JT, Kahn MA. Glandular odontogenic cyst: analysis of 46 cases with special emphasis on microscopic criteria for diagnosis. Head Neck Pathol 2011; 5(4): 364.

[24] Semba I, Kitano M, Mimura T, Sonoda S, Miyawaki A. Glandular odontogenic cyst: analysis of cytokeratin expression and clinicopathological features. J Oral Pathol Med 1994; 23(8): 377.

[25] Kaplan I, Anavi Y, Manor R, Sulkes J, Calderon S. The use of molecular markers as an aid in the diagnosis of glandular odontogenic cyst. Oral Oncol 2005; 41(9): 895.

[26] Vered M, Allon I, Buchner A, Dayan D. Is maspin immunolocalization a tool to differentiate central low-grade mucoepidermoid carcinoma from glandular odontogenic cyst? Acta Histochem 2010; 112(2): 161. 
[27] Lo Muzio L, Santarelli A, Caltabiano R, et al. p63 expression in odontogenic cysts. Int J Oral Maxillofac Surg 2005; 34(6): 668

[28] Re M, Santarelli A, Mascitti M, et al. Trail overexpression inversely correlates with histological differentiation in intestinal- type sinonasal adenocarcinoma. Int J Surg Oncol 2013; 2013: 203873.

[29] High AS, Main DM, Khoo SP, Pedlar J, Hume WJ. The polymorphous odontogenic cyst. J Oral Pathol Med 1996; 25(1): 25

Received: September 19, 2013

Revised: December 13, 2013

Accepted: December 17, 2013

(C) Mascitti et al.; Licensee Bentham Open.

This is an open access article licensed under the terms of the Creative Commons Attribution Non-Commercial License (http://creativecommons.org/licenses/by-nc/3.0/) which permits unrestricted, non-commercial use, distribution and reproduction in any medium, provided the work is properly cited. 